\title{
Hearing Impairment from the Islamic Perspective: A Review
}

Sarah Rahmat, Nur Ain Othman, Nur Hafizah Sulaiman, Masnira Jusoh, Mohammad Haseef Izani, Ahmad Aidil Arafat Dzulkarnain, Nur 'Azzah Zakaria, Nur Hanisah Tukiran, Noraidah Ismail, Marina L. Alisaputri @ Marina Lamri, Saiful Adli Jamaluddin, Juliana Aminah Marhaban, W. A. Wan Aslynn, Nor Azrita Mohamed Zain, Nurlin Ali Hanafiah

Department of Audiology \& Speech Language Pathology, Kulliyyah of Allied Health Sciences, International Islamic University Malaysia Kuantan.

\section{ABSTRACT}

Introduction: This discussion paper aims to synthesise available literature on hearing sciences from Islamic perspective and to relate this to the current hearing care practices. The paper focuses on several main scopes: i) the importance of sense of hearing from Islamic and scientific perspectives ii) impacts of hearing impairment iii) limitations in understanding and practicing Islamic teaching due to hearing impairment, iv) Islamic responsibility towards people with hearing impairment, v) current available methods to facilitate Islamic practices among hearing impaired people, and vi) incorporating Islamization in hearing care practice. Design: Narrative review and synthesis Method: Related publications and references were identified through several ways: i) by structured searches in PubMed, Google scholar, Web of Knowledge and Science Direct using the combinations of 'Islam', 'hearing impairment', 'hearing loss', 'hearing', 'social', learning', 'memory', 'disability', 'Islamic responsibility', and 'learning for deaf' as key words, ii) by inspecting the reference lists of relevant articles, and iii) by identification of relevant references from Quran and Hadith by authors who have background in Quranic studies. Results: The number of publications within the audiology field, which address the aforementioned scopes, is rather limited. Additionally, a review and synthesis of literature from other related fields such as medical, health, and education, with references from Quran and Hadith, were also carried out to facilitate the discussion of the above mentioned scopes. Conclusion: This paper concludes that there is an emerging trend for the studies of hearing and Islam in the literature. Facilitating hearing impaired people in understanding and practicing Islam becomes a shared obligation for parents, society, and the patients themselves. This discussion also identifies that there is a need for more contributions from Muslim scholars in integrating and implementing the Islamic principles in current hearing care practices.

KEYWORDS: Hearing impairment; Islamic perspective; Impact of hearing impairment; Islamic understanding \& practice, Islamic responsibility.

Hearing is an important sense in ensuring good communication, education, quality of life, as well as economic growth. ${ }^{1,2}$ Although there is a profuse scientific literature focusing on understanding the nature of hearing sense and the impact that results from losing this sense, limited literature discussing this matter from Islamic point of view gave rise to this review. This paper answers five questions: 1) What is the position of the sense of hearing from Islamic and scientific perspectives?, 2) What is hearing impairment and what are its effects?, 3) What are the limitations faced by people with hearing impairment in understanding and practicing Islam? 4) Who hold the responsibility to assist those

\section{Corresponding author:}

Sarah Rahmat

Department of Audiology \& Speech Language

Pathology,

Kulliyyah of Allied Health Sciences, International Islamic University Malaysia, Jalan Sultan Ahmad Shah, 25200 Kuantan, Pahang, Malaysia

Email: sarahrahmat@iium.edu.my with hearing impairment?, 5) What are the current methods available to facilitate Islamic practices among the hearing impaired?, and 6) How could Islamization be incorporated into hearing care practices?

The Importance of Sense of Hearing from Islamic and Scientific Perspectives

The word "hearing" has been frequently associated with "seeing" in the Quran that shows that much emphasis is given to these two senses in Islam. ${ }^{3}$ Allah has explained the creation of the auditory system from the embryologic stage, and that the creation of the auditory system preceded the creation of the visual system:

"We have created the human from a (sperm) drop, a mixture, testing him; we made him to hear and see" (Quran, 76: 2).

The Quran has provided a lot of evidence and explanation on the nature and functions of the auditory system prior to the findings from the 
modern, scientific investigations. For example, there is evidence in the Quran that hearing sense is active at all time even when a person is in the stage of unconsciousness, consistent with later research findings. ${ }^{4}$

\section{"So into the cave, we have set the senselessness curtains on their ears for several years" (Quran, 18: 11).}

The following sections will focus on: i) the development of the auditory system, and ii) the functions of hearing from Islamic and scientific perspectives in learning, in attaining good faith, and in ensuring good quality of life.

\section{Auditory System Maturation}

Allah mentioned about human development in one of the verses in the Holy Quran:

"And certainly did we create man from an extract of clay. Then we made the spermdrop into a clinging clot, and we made the clot into a lump [of flesh], and we made [from] the lump, bones, and we covered the bones with flesh; then we developed him into another creation. So blessed is Allah, the best of creators" (Quran, 23: 1214).

This verse has described the different stages of prebirth human development before this was further investigated by modern scientists some 1400 years later in a discipline called embryology. ${ }^{5}$ As mentioned in the verse, three processes are involved in pre-birth human development; "Nutfah", "Alaqah" and "Mudghah". Allah mentioned about the early human creation which involved fertilization, the development of the human structures, and the growth of the foetus. The development of the auditory system is also involved in these processes.

The auditory system consists of sensory organ that is controlled by the brain. Most of the sensory organ structures will mature at birth although a few of the other structures continue to increase in size until adulthood. ${ }^{6,7,8}$ On the other hand, the brain structures and its function will continue to develop until adulthood, between 16 and 20 years old, where it reaches maturity. A major factor determining the success of the maturation process is the collection of sufficient auditory input. This means that humans need to be able to hear and gain new "hearing experience" for this neural maturation process to continue until the maximum maturational period. The experience gained through hearing and listening will enhance brain functions, as it will cause the brain cells generally to increase in power and strength. The brain region in charge of hearing is inter-connected with the brain region in charge of speech and language, which is interrelated with the cognition area. There is strong evidence from the literature that hearing, speech, language, and cognition are functionally interrelated. ${ }^{9}$ For example, hearing is a prerequisite to acquire speech and language, and speech and language (including sign language) are important in acquiring normal cognitive abilities.

\section{Sense of Hearing and Learning Process}

In Islam, God is the ultimate source of knowledge and the Quran is the primary source of religious learning. The Arabic term Quran is a verbal noun that carries the connotation of a "continuous reading," "recital," or message that is recounted or listened to repeatedly. Thus, the term may be translated into English as "recitation," "recital," or even "teaching." Learning is compulsory for every Muslim, as Rasulullah mentioned in Hadith:

\section{"Narrated Anas ibn Malik: Allah's Messenger (peace be upon him) said: The seeking of knowledge is obligatory for every Muslim; and the imparting of knowledge to the non- deserving is like putting necklaces of jewels, pearls and gold around the necks of swine" - Al-Tirmidhi Hadith - 74. ${ }^{10}$}

Learning can be defined as "a process by which experience or practice results in a relatively permanent change in behaviour or potential behaviour". ${ }^{11}$ People of all ages learn best from meaningful experiences. Piaget (1958) mentioned that from birth onwards, information comes into the brain through first-hand experiences with things, people, and feelings, which depends entirely on vision, hearing, touch, smell, and taste. ${ }^{12,13}$ These five senses are the primary means we use to gain new knowledge as well as in the learning process. Pitts (2012) noted that human rely heavily on the senses to process information during learning. By using many senses to gain information, learning will be more meaningful and useful, and more cognitive connections and associations will be made with a concept. ${ }^{11,14}$

Although learning process involves all five senses, it is estimated that $95 \%$ of what we learn about the world around us comes through vision and hearing alone. ${ }^{15,16}$ The importance of hearing is supported in the Quran as Allah encouraged that the recitation of the Quran to be performed loudly to make the reciter and people around him listen to the message that Allah wanted to convey.

\section{"Listen to God's verses when they are recited," and should not "become arrogant, as if [one] had not heard them" (Quran, 45:8).}

In the following Hadith, Rasulullah mentioned that he loved listening to the Quranic recitation from other people, and that the act of Rasulullah crying upon listening to the verse recited by Abdullaah ibn Mas'ood, is proof that learning and reflecting (via listening) has taken place: 
'Abdullaah ibn Mas'ood may Allah be pleased with him said: "The Prophet sallallaahu 'alayhi wa sallam (may Allah exalt his mention ) told me: "Recite the Quran for me." I said: "How shall I recite the Quran for you while it was revealed to you?" He replied: "I like to hear it from others." So, I recited Chapter An-Nisaa' [Quran: 4] and when I reached the Saying of Allah (which means): \{so how [will it be] when We bring from every nation a witness and We bring you, [O Muhammad], against these [people] as a witness?\} [Quran 4:41], he said: "Stop now"; then I found his eyes were overflowing with tears." [Al-Bukhaari and Muslim].

Our hearing constantly supplies us with vital information, as well as causing us to experience emotions and recall memories. Theoretically, learning is the capability to modify information already stored in memory based on new input or experiences. ${ }^{11}$ Memory is contingent on prior learning. Our sensory system can hold numerous items simultaneously, but only momentarily. Learning is an active process that involves sensory input to the brain, which occurs automatically. The process also involves the ability to extract meaning from sensory input by paying attention to it long enough to reach working (short-term) memory, while consideration of information transfer into permanent (long-term) memory takes place. ${ }^{17}$ Cowan (1988), as cited in Morris and Moisto (2005) stated that visual information may disappear from the visual register even more rapidly than auditory information. Iconic memories of visual information would last 0.3 seconds, while echoic memories of auditory information would last about four to five seconds. Therefore, our brain has a longer time to further process incoming auditory information, and the information has more tendency to be kept in the long-term memory compared to visual information.

\section{Sense of Hearing and Iman}

In the Quran, the words 'hear' and 'listen' are mentioned recurrently, alongside 'obey' (the manifestation of Iman), thus reflecting the strong relation between Iman and hearing.

"The Messenger has believed in what was revealed to him from his Lord, and [so have] the believers. All of them have believed in Allah and His angels and His books and His messengers, [saying], "We make no distinction between any of His messengers." And they say, "We hear and we obey. [We seek] Your forgiveness, our Lord, and to You is the [final] destination." (Quran, 24: 51).

"The only statement of the [true] believers when they are called to Allah and His Messenger to judge between them is that they say, "We hear and we obey." And those are the successful". (Quran, 24: 51).

The relationship between hearing and Iman becomes even more significant as most verses on purity of heart and understanding are related to hearing (Quran, 16:78; 8:1). Allah has also associated the sign of weak Iman with hearing as He mentioned:

\section{"Allah has set a seal upon their hearts and upon their hearing, and over their vision is a veil. And for them is a great punishment. (Quran, 2: 7).}

The above examples of Quranic verses showing the relation of hearing and Iman could be explained by the fact that hearing is a vital sense in facilitating learning and maintaining good memory. The aforementioned verses indicate that a good hearing is crucial in acquisition of Islamic input and concepts, while good memory is important in performing Islamic obligations. For example, in Solat (a prayer) there are many recitations that must be memorised; the memorisation process could be facilitated by listening, as the auditory input has more tendency to be stored in long-term memory. ${ }^{11}$ This reasoning could shed some light on the relationship between hearing and Iman.

\section{Impact of Hearing Impairment Hearing Impairment and Cognitive Development}

Hearing impairment is a silent disorder which may not be detected until the problem becomes severe. World Health Organization defines hearing impairment as hearing thresholds of $25 \mathrm{~dB}$ or greater in both ears. Hearing impairment that leads to disability is known as disabling hearing impairment, which is defined as "hearing impairment greater than $40 \mathrm{~dB}$ in the better hearing ear in adults and a hearing impairment greater than $30 \mathrm{~dB}$ in the better hearing ear in children". ${ }^{18}$

Hearing impairment that exists at birth could occur because of the abnormality in the embryonic development process resulting in dysfunction of certain parts within the auditory system. One of the common structures that may be congenitally abnormal is the hair cells, which lie inside the organ of hearing (cochlear). Dysfunction of these fine structures results in hearing impairment, which, without appropriate intervention (e.g., hearing amplification and rehabilitation) could lead to issues with speech and language development. Delay in neural-maturation in the auditory cortex contributes to the difficulty in acquiring speech and language, although compensations may be possible with appropriate intervention. Individuals with language difficulties may also have difficulties in many cognitive skills ${ }^{9}$ such as moral reasoning; a skill that an individual needs to comprehend morality boundaries or limits. Children develop moral reasoning abil=ity in stages where they learn to relate their discomfort, guilt, and anxiety with wrongdoings. ${ }^{19}$ The development in moral reasoning has been found to be highly correlated with 
IMJM Volume 17 Special Issue No 2

language development. ${ }^{20}$ Therefore, it can be argued that hearing impairment and language difficulties secondary to hearing impairment may impede moral reasoning development. Children with congenital hearing impairment may also suffer from delay in reading comprehension ${ }^{21}$, and an average deficit of approximately six months to one year in mathematics or reading achievement by10 years old. 22,23

\section{Hearing Impairment, Education, and Good Quality of Life}

In early childhood, hearing plays an important role in speech and language development. Through hearing, children learn to imitate speech sounds, discover word meanings, and ultimately learn how to speak. Children with hearing impairment who do not receive proper intervention will not receive enough auditory stimulation. As a consequence, this will delay their language acquisition and prevent them from learning to speak. According to a few studies, even a mild degree of hearing impairment may cause delay in speech and language development. ${ }^{24}$ Due to that, early identification of hearing impairment is crucial as it is associated with significantly better speech and language development. ${ }^{25}$

Besides that, an impairment in hearing may also affect children's academic achievement. Davis, et al. (1986) revealed that the academic performance tended to decrease with increased severity of hearing impairment. The poor academic achievement experienced by hearing impaired children was reported to be strongly related with the delay in speech and language development. ${ }^{24}$

Moreover, hearing also enables people to socialize and work with others. It helps us in a process of connecting with one another and with the environment.Failure to establish social relationships may lead to a feeling of isolation and even depression which may affect mental health of an individual. This is supported by Tambs (2004) who found significant effects of hearing impairment on mental health particularly depression and reduced self-esteem among young and middle-age hearing impaired adults. ${ }^{26}$ In children, hearing impairment was found to be a significant cause to social problems. They were more likely to show some aggressive behaviours and face difficulty adjusting to the school which again may lead to a feeling of isolation. $^{24}$

\section{Limitations in Understanding and Practicing Islamic Teaching Due To Hearing Impairment}

Religion plays a significant role in Muslims' life. The understanding of religious input and knowledge, however, may be hindered in individuals with hearing impairment. Consider for instance Quranic recitation ability: the basic skill possessed by majority Muslims. Learning to recite the Holy Quran requires one to have the ability to hear, listen, and articulate the Arabic phonics in the appropriate manner. Individuals with hearing impairment (especially those with no or late intervention) generally have difficulty in acquiring speech. They have problems in, for example, identifying consonant phonemes that are normally high-pitched in nature. In addition they also have a difficulty in understanding grammatical aspects of Arabic (tajweed) language, and have issues with fluency and producing melodic voice for Quranic recitation. ${ }^{27}$

A survey conducted involving students with hearing impairment in a Politeknik in Malaysia showed that these students have poor ability to perform basic prayer's recitations in Arabic language. ${ }^{28}$ Only $20 \%$ of the students knew how to recite Al-Fatihah, while the other $80 \%$ had poor recitations skill. Majority of the students (70\% - $100 \%)$ agreed that the difficulty to memorize the recitations in prayer, and lack of continuous teaching and learning on the recitations in prayers were the main factors contributing to their poor performance. Another study conducted in Malaysia investigated the factors affecting the Quranic recitation learning in children with severe and profound hearing impairment fitted with a cochlear implant. The findings showed that self-motivation, interest, self-improvement, and self-initiated learning were the most significant factors which facilitated the learning of the Holy Quran among the children. ${ }^{27}$ From the teachers' perspectives factors such as: the difficulties of the students with hearing impairment in understanding abstract concepts in Islamic teachings, poor memorization skill, poor speech ability, improper classroom setting and environment, and unsupportive parental attitudes were contributing to the challenges in implementing Islamic education in children with hearing impairment..$^{8,24}$

Islamic concepts such as "tawhid" (belief) and "muamalah" (social relation) require a high order thinking ability in order to be comprehended. Given that the human cognitive development and moral reasoning milestones are very much dependent on hearing ability, there is a possibility that children with hearing impairment, without the appropriate intervention, have difficulties in understanding Islamic concepts. Delay in cognitive development among children with hearing impairment is likely to affect their understanding of the Islamic "usulfiqh", such as the understanding of the concept of "halal" (permissible) and "haram" (not permissible). The concept of "halal" and "haram" requires high order thinking and high order of moral and internal values within the brain. This is consistent with the report from teachers saying that children with hearing impairment have difficulty understanding important concepts in Islamic teachings. ${ }^{29,30}$

As a summary, there are possibilities that the development of moral reasoning may be impeded in children with hearing impairment. Together with the report on the lack of Islamic input received by 
children with hearing impairment, ${ }^{27,28,29,30}$ we could not deny the possibility that this population may have the tendency to involve in social misconduct. Thus, appropriate intervention is vital to overcome the disabilities resulting from hearing impairment in this population, so that they will have equal opportunities in learning and practicing Islam as other normal-hearing citizens.

\section{Islamic Responsibility towards People with Hearing Impairment}

Islam gives much emphasis to providing assistance and support to people with disabilities, including hearing impairment. As discussed previously, hearing is an important sense involved in gaining good faith and in performing Islamic obligation. Thus providing treatment and assistance for people with hearing impairment becomes a collective Islamic responsibility shared by the government, the community, the family, and the individual themselves.

\section{Government responsibility}

According to the principle of Syariah (Maqasid AsShariah), the first objective of Maqasid As-Shariah is the principle of 'Necessity' (Dharuriyah), a matter which if neglected, could bring harm to this world, as well as to the hereafter (the akhirah). ${ }^{31}$ Protection of life (Nafs), posterity (Nasl), property (Mal), reason ('Aql), and protection of faith or Din (in terms of prayers, zakat, fasting and Hajj) are elements of necessity (Dharuriyah). According to the Maqasid As-Syariah, providing means to understand and practice religion becomes a necessity as a way to protect faith, and should be of priority to the government. Therefore, an establishment of welfare and support system prioritizing all the aforementioned elements is necessary.

For an Islamic country (e.g., Malaysia), the welfare and support system provision should reach all Muslim citizens particularly the hearing impaired community as there was evidence from previous studies that this population may perform poorly in terms of Islamic practice, such as Solat, and Quranic recitation. ${ }^{27,28}$ This could be partly due to improper approaches used in the delivery of Islamic input to suit the needs of individuals with hearing impairment. ${ }^{29,30}$ Hence, the needs and challenges faced by individuals with hearing impairment in learning and practicing Islam must be thoroughly understood as this will provide the relevant parties the direction as to how this population could be assisted.

\section{Community Responsibility}

Islam gives a lot of emphasis to the roles of public or community in providing assistance and facilitating those who are in need. In the following Hadith, Rasulullah (P.B.U.H.) has mentioned that Allah will reward whoever fulfils the need of the needy. The word 'whoever' in the hadith shows that the responsibility falls onto no specific person, but to the public community in general. The needy may include those who are in need of material assistance or other assistance in performing their daily duties, including those with disability.

"On the authority of Abu Hurayrah (may
Allah be pleased with him), that the
Prophet (peace be upon him) said:

Whoever removes a worldly grief from a believer, Allah will remove from him one of the grieves of the Day of Resurrection. And whoever alleviates the need of a needy person, Allah will alleviate his needs in this world and the Hereafter. Whoever shields [or hides the misdeeds of] a Muslim, Allah will shield him in this world and the Hereafter. And Allah will aid His slave so long as he aids his brother. And whoever follows a path to seek knowledge therein, Allah will make easy for him a path to Paradise. No people gather together in one of the Houses of Allah, reciting the Book of Allah and studying it among themselves, except that sakeenah (tranquility) descends upon them, and mercy envelops them, and the angels surround them, and Allah mentions them amongst those who are with Him. And whoever is slowed down by his actions, will not be hastened forward by his lineage". (Hadith 36, n.d.).

The roles of a community in assisting individuals with disability would include: i) providing a supportive environment for the disabled individuals to function in daily activities, ii) providing an inclusive environment such that the disabled individuals can participate within a community, iii) diminishing the stigmata of certain cultural beliefs that may hamper individuals' effort to seek treatment, and iv) providing equal opportunities for every single community member to seek help. ${ }^{32}$ In dealing with hearing impairment issues, creating awareness among the public is vital, yet it remains a neglected priority. ${ }^{33}$ The community plays a vital role in creating and boosting public awareness of hearing impairment, its effects, the available treatments, and the consequences of untreated hearing impairment. This could be done by: i) recruiting local collaborators in the awareness program (in the case of non-local non-native organizers), ii) respecting the community structure by involving the local community leader in the program, iii) determining and addressing the health concerns of a community (via survey and interview), and iv) encouraging ownership and individual responsibility to seek treatment. ${ }^{33}$ This way we could empower the community through the community, which can be achieved by the involvement of NGOs and other community organizations.

\section{Family Responsibility}

Islam emphasizes the concept of taking care of disabled persons for whom special attention, 
assistance, and care need to be given. Allah has mentioned in the Quran:

\begin{abstract}
"And your Lord has decreed that you not worship except Him, and to parents, good treatment. Whether one or both of them reach old age [while] with you, say not to them [so much as], "uff," and do not repel them but speak to them a noble word. And lower to them the wing of humility out of mercy and say, "My Lord, have mercy upon them as they brought me up [when I was] small. (Quran, 17: 23-24).
\end{abstract}

"O you who have believed, when you contract a debt for a specified term, write it down. And let a scribe write [it] between you in justice. Let no scribe refuse to write as Allah has taught him. So let him write and let the one who has the obligation dictate. And let him fear Allah, his Lord, and not leave anything out of it. But if the one who has the obligation is of limited understanding or weak or unable to dictate himself, then let his guardian dictate in justice. And bring to witness two witnesses from among your men. And if there are not two men [available], then a man and two women from those whom you accept as witnesses - so that if one of the women errs, then the other can remind her. And let not the witnesses refuse when they are called upon. And do not be [too] weary to write it, whether it is small or large, for its [specified] term. That is more just in the sight of Allah and stronger as evidence and more likely to prevent doubt between you, except when it is an immediate transaction which you conduct among yourselves. For [then] there is no blame upon you if you do not write it. And take witnesses when you conclude a contract. Let no scribe be harmed or any witness. For if you do so, indeed, it is [grave] disobedience in you. And fear Allah. And Allah teaches you. And Allah is Knowing of all things" (Quran, 2: 282).

The above two verses clearly depict that the responsibility towards the disabled falls onto their guardians and children, or family members. This notion applies to any type of disability, including hearing impairment. The primary roles of parents in this case is to socialize, teach and promote the physical and emotional well-being of children. ${ }^{34}$ Previous study has shown that the family institution has significant influences on the cognitive development of deaf children, in which deaf children will benefit from parental attention and investment. ${ }^{35}$

\section{Individual Responsibility}

Islam means total submission to the will of Allah through observing His orders and refraining from the forbidden deeds. All Muslims have their Islamic responsibility towards themselves, called as 'fard al muslim'. Each Muslim must fully understand Aqidah of Islam (firm belief), Ibadah in Islam (worship), and akhlaq in Islam. ${ }^{36}$

Unlike those with normal hearing, the acquisition of Islamic input and the ability to perform Islamic obligation may be hindered in people with hearing impairment. However, having hearing impairment or other disability does not waive one's responsibility of fulfilling the Islamic obligations:

"From Abu Hurairah: A blind man came to the Prophet and said: O messenger of Allah, I do not have one that led me to the mosque. Then the Prophet gave rukhsoh (waivers) to him, when he is going to leave, the prophet calls him again and asked: "Do you hear the call to prayer (azan)? He said: Yes. Then he said: "Fill the call." (a Hadith narrated by Imam Muslim)

واجبهو به إلا الواجب يتم لا " There is a Fiqh method called "Lwhich means, actions that are to complement the mandatory, are also obligatory. ${ }^{37}$ Thus, it becomes the responsibility of people with hearing impairment to seek treatment in order to enable them to gain Islamic input and to fulfil their Islamic obligation:

\begin{abstract}
"Surely God does not change the condition on someone until they change that which is in themselves" (Quran, 13:11).
\end{abstract}

\section{Current Available Methods to Facilitate Islamic Practices Among Individuals with Hearing Impairment and Room for Improvement}

Conventional Islamic teaching and learning process is often conducted in the form of lectures, classes and group discussions, which means adequate auditory skills are necessary. Muslims with hearing impairment who depend a lot on their visual ability would be at a disadvantage. Furthermore, the acquisition of knowledge through reading alone may also be hindered in this population. There is evidence in the literature that relates hearing impairment with illiteracy. ${ }^{38}$ This section will describe several works that have been done around the globe to support and realise the professed ideology of social inclusion in Islam.

\section{Related Works around the World}

Activities to help Muslims with hearing impairment to learn Islam, though scarce, are being initiated by government and non-government organizations. Sign languages such as British Sign Language (BSL), American Sign Language (ASL), Saudi Sign Language (SaSL) are often used as the mode of communication. Resources for Islamic education are now available in forms that are appropriate for those with hearing impairments, such as national 
education curriculum, online videos, smart phone applications, halaqah (Islamic classes), workshops, and conferences.

\section{National Education Curriculum and Educational Material}

Several governments such as Malaysia and Saudi Arabia have made proactive efforts to include Islamic education in the national education curriculum. This curriculum is not only used in the mainstream education but also in special education. 30,39 Children with special needs, including those with hearing impairment, are exposed to formal Islamic Education as early as preschool.

In addition to the curriculum, there are governmentfunded projects that aim to assist people with hearing impairment to learn Islam. The Ministry of Endowment Qatar, for instance, has recently launched a website for the deaf in 2016called'islamweb.deaf' ${ }^{40}$ The website (http://deaf.islamweb.net) provides translations of sharia and sharia-related topics into Arabic, ASL and BSL. There are also animations for kids, stories of muallafs and also avenues to seek for consultation. Another example is a project by Elhadj (2012) in which multimedia materials for deaf people in Saudi Arabia are developed. The educational materials allow the written content of Islamic education to be automatically translated from the Arabic to SaSL using 3D animation techniques called Avatars. ${ }^{41}$ Among the topics that are covered are the prayer, pilgrimage, fasting, zakat and cleanliness.

\section{Online Videos and Smartphone Applications}

A few websites such as 'alisharah.com'42 and 'globaldeaf-muslimcanada.com'43 http://www. alisharah.com' and 'http://www.globaldeafmuslimcanada.com' are now available that allow free access to Islamic input designed for individuals with hearing impairment. These websites are created by deaf societies or non-government organizations, such as Global Deaf Muslim and AlIsharah. The customised modes of information delivery_include video recordings of Islamic classes with interpreters for adults, reproduction of Islamic videos with sign language interpretations, adzan (call to prayer), and also al-Quran translation. However, these resources are only available in the BSL and ASL.

There is also a free smart phone application available known as 'Prayer for Deaf'. It was created by Takbir Publishers (2014), and uses English and Urdu as its medium. It provides descriptions on how to perform wudhu, steps of performing daily prayer, after prayer supplication, and also Janazah (Funeral) prayer.

Halaqah, Conferences and Other Services

Halaqah or Islamic classes for Muslim adults and children with hearing impairment are being initiated by deaf organizations. The classes are conducted in the mosques or Islamic centres by an ustaz (religious teacher) in the presence of an interpreter, who translates the lesson into sign language. The classes are also recorded and uploaded online (see 'alisharah.com" ${ }^{42}$ and 'globaldeafmuslimcanada.com, ${ }^{43}$ http://www.alisharah.com,http:/ /www.globaldeafmuslimcanada.com for more information).

Knowledge sharing among Muslims with hearing impairment is not only limited to small scale classes. The first International Conference for Deaf Muslim (ICDM), initiated by Global Deaf Muslim, was successfully organized in November 2013 in Qatar. ICDM serves as a platform to discuss challenges and issues that are faced by Muslims with hearing impairment in acquiring input in Islamic teaching. The conference also allowed exchanges of ideas and good practice in providing Islamic Education for Muslims with hearing impairment. The second ICDM was held in Malaysia in October 2016 with the theme: "Islam for Deaf: Our Community, Our Future".

Besides direct Islamic education input, there are other customised services meeting the need of people with hearing impairment that contribute to general improvement in quality of life. These include matrimonial services, employment services, as well as Hajj and Umrah programs Workshops and training for interpreters and volunteers who work with people with hearing impairment are also available, for example, the Islamic vocabulary workshops. ${ }^{42,43}$ (http://www.alisharah.com,http: / /ww w. globaldeafmuslimcanada.com).

\section{Related Works in Malaysia}

In Malaysia, efforts to assist Islamic learning among people with hearing impairment have been initiated at government level, related organizations, and individuals.

\section{National curriculum}

Islamic education in Malaysia is included in the special education curriculum from the preschool years. ${ }^{44}$ At the primary school level, 150 minutes per week, with 30 minutes per session are allocated for Islamic teachings. The components that are taught include 1) basic tilawah al-quran (i.e., recitation, understanding and memorization), 2) Islamic manners and characters, 3) basic ulum Syariah (i.e., aqidah, ibadah, sirah), and 4) Jawi writing. ${ }^{30}$

In 2005, the government started another programme known as $\mathrm{j}-\mathrm{QAF}$, in order to enhance Islamic education, that was later extended to exclusive special education school in 2009. ${ }^{45} \mathrm{j}$-QAF emphasises on Jawi writing, Al-Quran reading, Arabic language and Fardhu 'Ain. j-QAF was incorporated into Islamic Education in 2015.

\section{Support from related organizations}

Several organizations in Malaysia are actively playing their part to help children with hearing 
impairments. The Foundation of Quranic Education for Special Needs Children (FAQEH Foundation), for example, is committed to help children with special needs to read and understand al-Quran through FAQEH method. Other examples are the Deaf Muslim Society of Malaysia (PRISMA) and Pahang Deaf Association (PADA) who organize frequent Islamic Classes or Halaqah for Muslim with hearing impairment by providing an interpreter for each session. PRISMA also had organized an umrah trip for the Muslim with hearing impairment in 2015.

\section{Fakih Method}

In view of the limited teaching and learning of AlQuran methods for children with hearing impairment, the Centre of Quranic Research (CQR) of University of Malaya, Malaysia, together with FAKIH Intellect Academy have developed a method known as FAKIH (Centre of Quranic Research (CQR), 2016). FAKIH is an acronym of $F$ : Faham (Understand), A: al-Quran, K: Kehidupan (Life), I: Insya-Allah/ (With Allah's Will), H: Hebat (Great). ${ }^{46}$ FAKIH method employs the use of numbers and colors to teach hijayyah (Arabic) letters, tajwid knowledge, and eventually recitation of Al-Quran using hand sign. ${ }^{46}$

The teachers and students are equipped with teaching materials and learning kits such as guide book for users, module worksheets, magnetic boards, and coloured and numbered magnetic buttons. ${ }^{46}$ The availability of these teaching materials and learning kits helps to overcome the issue of limited appropriate teaching materials and learning aids for teachers and children with hearing impairment to teach and learn Al-Quran. ${ }^{47}$

Sayuti, Sabdan, Alias, and Jomhari (2012) reported that students with hearing impairment who used FAKIH method were able to read and recite $\mathrm{Al}$ Quran fluently using the hand sign. ${ }^{48}$ FAKIH method also increases the effectiveness in the process of teaching and learning of Al-Quran and improved satisfaction level in teaching and learning in the teachers and students with hearing disabilities. ${ }^{46}$

\section{IT-facilitated learning}

A preliminary study on challenges in teaching and learning process involving Politeknik students with hearing impairment has been carried out previously. ${ }^{49}$ It was shown that in addition to the difficulties in dealing with different cognitive levels of the students with different hearing abilities, insufficient number of language interpreters provided in the polytechnic was also an issue. In response to the aforementioned problems, Abdul Mutalib et al., (2012) developed a software that could be used especially for the Pendidikan Islam course, known as Koswer Pendidikan Islam Tunakerna (KOSPIT) (2012). ${ }^{1}$ The users' feedbacks of this software were generally positive. The users found the use of sign language and simple texts for explanation about subject matters enjoyable and they appreciated the availability of video elements which helped their understanding.
Another available method to increase understanding about Islam among individuals with hearing impairment is Islamic-themed web application that has been introduced by Mokhtar and Anuar (2014). Although this web application does not give Islamic input directly, it introduces finger spelling and signs for Islamic words and sentences. ${ }^{50}$ These finger spellings and signs are not only useful for facilitating Islamic teaching and learning among hearing impaired community, it also helps the public to share Islamic information with the community.

Baharudin and Abdul Majid (2015) have developed a website known as 'e-solatpekak.com' to complement the Islamic Education syllabus. The website was designed to help primary school students with hearing impairment, especially those in Year 2 and Year 3 of primary school to understand and perform the daily prayers accurately. ${ }^{51}$

\section{Incorporating Islamization in Hearing Care Education and Practice}

As discussed previously, the efforts in incorporating Islamic elements in hearing care education and in the process of facilitating Islamic understanding and practice among people with hearing impairment should be carried out at many levels. The following sections discuss the recommendations of how installation of Islamic elements in hearing care practices could be carried out in different settings: i) clinical, ii) academic, and iii) industrial settings.

\section{Clinical Setting: Incorporating Islamic Input in the Rehabilitation Process}

When dealing with children with hearing impairment, an intervention should be done as soon as possible, such as to identify hearing impairment before 3 month of age, and to intervene before 6 months of age, as outlined by American SpeechLanguage-Hearing Association (ASHA). ${ }^{52}$ This is crucial in ensuring the child has the chance to undergo normal language and speech development compared to his or her normal hearing peers.

Among the intervention options that are widely available for children with hearing impairment are cochlear implant and hearing aids. Following the fitting of hearing aids and the implantation process of cochlear implant, auditory training and rehabilitation process is crucial in ensuring that the child or wearer gets the optimum listening benefits from the devices. Music has been identified as an important tool that can be used in the auditory training and rehabilitation process for hearing impaired children. ${ }^{53}$ The use of music listening activities, either via passive or active listening can give huge benefits to the language acquisition, attention and perception of hearing impaired children. ${ }^{54}$ The use of music in auditory training can assist the acquisition of suprasegemental (stress and intonation) perception skill. ${ }^{55,56}$ In listening stage, 
the detection of suprasegmental elements of speech is among the early listening skills developed in children. ${ }^{54}$ Previous studies have also suggested the use of nursery rhymes (which contained multiple suprasegemental elements) as effective auditory training tools in the rehabilitation process involving hearing impaired children. ${ }^{54,55}$

From the Islamic perspective, Azan and Quranic recitation both contain beautiful melody, and can be used as a form of music therapy and tools for auditory training for Muslim children with hearing impairment. Islam stressed the use of this form of 'music therapy' as early listening stimulation, in accordance with a prophetic tradition to get the new born to listen to Azan right after the delivery:

\section{"Abu Rafi' saw Nabi Sallahu Alayhi Wa Sallam perform Azan in the ear of Hasan Radiyallahu Anhu when Fatimah gave birth to him" (Narrated by Abu Daud and at- Tirmizi, cited in Ismail \& Mohd Azrul Azlen, 2009). ${ }^{58}$}

The benefits of listening to Azan is not limited to it being therapeutic, it also relates to the purification of the soul as early as a child is born. This includes getting the child to first listen to the greatness of Allah, and protection of the child from the devil. ${ }^{99}$

In addition to parents, audiologists or other hearing care professionals are also usually present when children with hearing impairment receive their first auditory stimulation via amplification (during first hearing aid fitting or cochlear implant switch-on). Audiologists, particularly those who are Muslims, should consider using Azan and Quranic recitations in the early hearing stimulation and as part of the continuous auditory training for Muslim patients. This could be an effort to follow the Sunnah and prophetic tradition, and at the same time gaining the proven benefit of sound therapy as part of auditory training for hearing impaired children.

Academic Setting: Integrating the Islamic Input in Hearing and Speech Sciences Curriculum

Audiologists and speech-language therapists are usually the main persons providing hearing care and involved in the management of hearing impairment and could potentially be mediators for conveying Islamic principles and practices to the hearing impaired society. For the audiologists and speechlanguage therapists to be able to provide such input, they have to be trained in the methods to instil Islamic values in populations with special needs during their studies.

Osman (2016) has outlined the Islamic values and principles that can be taught to medical students. Values and principles such as medical ethics and medico legal issues pertaining to maqasid al shariah, medical Figh and appreciation of the anatomy and physiology as examples of the bounty of The Creator are all applicable to the students of any healthcare programs. $^{60}$

Literature search provided no result on the Islamic input in hearing and speech sciences curricula. However, a review of the syllabus of the Bachelor of Audiology program in the Kulliyyah of Allied Health Sciences, IIUM reveals several courses that contribute to the Islamic input in the curriculum Courses such as 'Islamic Worldview', 'Ethics and Fiqh for Everyday Life' and 'Islam, Knowledge and Civilization' are some examples of courses that show how Islamic values are imbedded in the audiology curriculum.

What may be considered in the future for tertiary education, therefore, is the inclusion of more objective and systematic Islamic practices and principles in courses related to hearing and speech sciences and health care. Issues such as figh ibadah for the hard of hearing and Quranic studies for those with speech and hearing problems for example can be included in the outline of the core courses instead of being taught indirectly through general courses. This also ensures that those values reach all students. This model has been used in the medical programs in IIUM and Universiti Sains Islam Malaysia (USIM), where modules on Islamic issues, such as ethics and $a d a b$ as Muslim medical practitioners, are delivered as part of the preclinical studies and clinical practicum. ${ }^{60,61}$

\section{Industrial Setting: Promoting Hearing Health Care Among the Employees}

Noise emitted from the usage of heavy machineries in high economic activities has posed a significant problem to workers and employers. Exposure to noise of sufficient intensity and duration may damage hearing. In adults, hearing impairment due to noise exposure is the second most important cause of hearing impairment after ageing. ${ }^{62,63}$ Internationally, the estimated prevalence of Noise Induced Hearing impairment is about $7 \%$ of the population in Western countries and $21 \%$ in developing countries. ${ }^{64}$ Workers in industries such as manufacturing, construction, transportation, agriculture and military are at risk of developing noise induced hearing impairment (NIHL) due to exposure to noise. ${ }^{65}$ Those who are working in industrial settings are inevitably exposed to noise, therefore hearing protection among them is very indispensable to avoid hearing problems. Allah has reminded His servants to protect themselves from destructions as stated in the following verse:

\section{"And spend in the way of Allah and do not throw [yourselves] with your [own] hands into destruction [by refraining]. And do good; indeed, Allah loves the doers of good" (Quran, 2: 195).}

\section{Raising awareness in the workplace}

Past studies concluded that barriers to an effective hearing impairment prevention program in manufacturing industries in Malaysia came from 
middle management as well as from workers. ${ }^{66}$ Based on the findings it seemed reasonable that something needs to be done to improve attitude and raise awareness among workers and management personnel. Workplaces must be informed that noise reduction is something crucial but feasible and should be regarded as such. It is also important to make employers and employees aware that hearing conservation programs do not only refer to personal hearing protection and audiometry; but also inculcating the positive safety attitudes among workers and health personnel. ${ }^{67,68}$ The negative beliefs and misperception held by occupational safety and health personnel was identified as a barrier to effective noise control in the workplace. Based on these findings, therefore, it seems reasonable to recommend better training for occupational safety and health officers to enhance their awareness of the noise control issues.

There are a few preventive measures that can be implemented by the company to raise awareness amongst workers. The preventive measures include the following:

1. Employers should always make sure that workers wear hearing protection devices (HPD) in a noisy environment or whenever the noise level is more than $85 \mathrm{~dB}(\mathrm{~A})$.

2. Employees must be trained to use HPD properly and to make sure that the devices are in a good condition and are adequate for the level of noise they are exposed to. Change it if the HPDs are damaged.

3. The workers must keep their ear protectors for their own use only and keep them clean to avoid irritation or infections of their ear canals.

4. Make sure that the duration of exposure to the noise is reduced if exposure is unavoidable (even with appropriate ear protectors). There are international standards for maximum duration of exposure depending on the intensity of the noise (Refer to Table 1).

5. Do not listen to music or use the earpieces as ear protection or 'distraction' from the external noise (not even under cup ear protectors). The earpieces of personal music players are not designed for noise protection and their loud volume in a noisy environment will only add up to the noise damage.

6. Inform workers to avoid exposure to solvents or protect themselves with appropriate facemasks. Solvents (varnish, paint, gasoline, other fuels, etc.) may also damage hearing.

7. If the workers' work involves exposure to both noise and solvents the risk of hearing damage is much greater than if they are exposed to both of them separately (e.g. car body work, noisy petrol plants, etc.). Tell them to maximize their ear protection and minimize the duration of exposure to these factors.

8. Avoid ototoxic medications. Their effects will add up to those derived from noise exposure.
9. Always wear a helmet when there is a risk of head injury (riding a motorbike, a bicycle, working with heavy equipment overhead, working in a building site, etc.). Even in hot and humid environments, it is better to sweat than to end up deaf or even dead from a head injury.

10. Ensure the workers get their hearing checked at least once a year (ideally every 6 months).

11. Seek medical advice if the workers already have a hearing impairment or ear condition, or if they notice any change in their hearing, tinnitus (noises or ringing in the ars), earache, ear discharge, itchiness, or any other ear symptoms.

Table 1: Permissible Noise Exposure Level

\begin{tabular}{c|c}
\hline Sound Level (dB A) & $\begin{array}{c}\text { Duration/Day } \\
\text { (Hrs) }\end{array}$ \\
\hline 90 & 8 \\
92 & 6 \\
95 & 4 \\
97 & 3 \\
100 & 2 \\
102 & 1 \\
105 & 1 \\
110 & $1 / 2$ \\
115 & $1 / 4$ or less \\
\hline
\end{tabular}

* Factories \& Machinery Act $19677^{69}$
* Factories \& Machinery (Noise Exposure) Regulations
$19899^{70}$

\section{CONCLUSION}

This review aims to observe the views on hearing sciences across the Al Quran and Hadiths. These categories were looked in light of the Islamic teachings: i) the sense of hearing; ii) hearing impairment and its impact towards the understanding of this religion; iii) islamic responsibility towards hearing impairment, iv) current available methods to facilitate hearing impaired people; and $v$ ) incorporating islamization in hearing care practice.

Hearing, as it is one of the five senses, is often associated with the attainment of good Islamic faith as it is evident in some of the surahs like $A l$ Baqarah, Al Nahl and Al Anfal. The word 'hear' is used straightforwardly in these sentences. The importance of hearing, which could lead to a better understanding of Islam among its worshipers, is established. The effects of hearing impairment in relation to Islamic concepts such as tawhid, responsibility and muamalah are also discussed in great length in this article. The use of Islamic knowledge also is analysed in relation to aural 
rehabilitation for children with hearing impairment.

This article listed the Islamic responsibility of the government, the community, the family and the individuals to the hearing impaired population. Available methods to facilitate Islamic practices among hearing impaired patients such as Halaqah, conferences, Faqih and web-based teaching as well as the National Education Curriculum and Educational Material concerning the hearing impaired are included in this review. This paper also highlights the importance of inculcating Islamic input in the hearing and speech sciences pedagogy. It is noteworthy that Islamic values such as ethics, $a d a b$ and Fiqh can be integrated in the curriculum. Finally, this review article also covers the notion of Islamization in the hearing care practice in which a good trend can be seen where awareness for better hearing protection is increasing in accordance with the Islamic teaching.

\section{ACKNOWLEDGEMENT}

Part of this review has been presented in 2nd World Congress on Integration \& Islamicisation II: Focus on Medical \& Health Care Sciences. This study was funded by Research Initiative Grant Scheme (Grant no: RIGS 16-125-0289) and Fundamental Research Grant scheme (FRGS15-236-0477). The authors would like to thank Amir Faisal for helping with final editing.

\section{REFERENCES}

1. Nachtegaal J, Smit JH, Smits CAS, et al. The association between hearing status and psychosocial health before the age of 70 years: results from an internet-based national survey on hearing. Ear and hearing 2009; 30(3), 302312.

2. Nelson DI, Nelson RY, Concha-Barrientos M, \& Fingerhut $M$. The global burden of occupational noise-induced hearing impairment. American J of Industrial Medicine 2005; 48, 446-458.

3. Rajabnejad MR Evaluating the position of ear and eye in Quran and Nahjolbalaghe, and the philosophy of ear precedence over eye in Quran and Nahjolbalagha. Quran and Medicine 2012; 1 (3) 8-12.

4. Johns Hopkins University: How Do We Hear While We Sleep? ScienceDaily [online]. Available at: www.sciencedaily.com/ releases/1998/04/980430044534.htm. Accessed September 20, 2016.

5. Saadat S. Human embryology and the holy quran: an overview. Int J Health Sci (Qassim) 2009; 3, 103-9.

6. Ponton CW, Eggermont JJ, Khosla D, Kwong B, \& Don M. Maturation of human central auditory system activity: separating auditory evoked potentials by dipole source modeling. Clin Neurophysiol 2002; 113, 407-20.

7. Ponton CW, Eggermont JJ, Kwong B, \& Don M Maturation of human central auditory system activity: evidence from multi-channel evoked potentials. Clin Neurophysiol 2000; 111, 220-36.

8. Wunderlich JL, Cone-Wesson BK, \& Shepherd R. Maturation of the cortical auditory evoked potential in infants and young children. Hear Res 2006; 212, 185-202.

9. Mayberry RI Cognitive development in deaf children: the interface of language and perception in neuropsychology. In: Segalowitz, S $\mathrm{J} \&$ Rapin, I (eds.) Handbook of Neuropsychology. Elsevier, 2002.

10. Al-Tirmidhi Hadith - 74 [online]. Available at: http://www.alim.org/library/hadith/ TIR/74http://www.alim.org/library/hadith/ TIR/74http://www.alim.org/library/hadith/ TIR/74. Accessed September 22, 2016

11. Morris CG, \& Maisto AA Psychology: An introduction (12th Ed.). Upper Saddle River, NJ: Prentice Hall, 2005.

12. McLeod SA Jean Piaget [serial online] 2015. Available at: www.simplypsychology.org/ piaget.html. Accessed May 26, 2016.

13. Piaget $J$ The growth of logical thinking from childhood to adolescence. AMC 1958, 10, 12.

14. Pitts A Learning is Multi-Sensory: How to Engage All the Senses so Children Really Benefit [online]. Available at: www.howtolearn.com. Accessed May 26, 2016.

15. Sense Information and Advice. The importance of Hearing and Eye Tests [online]. Available at: www.sense.org.uk. Accessed May 26, 2016.

16. Ringoen $C$ Hearing, Learning and Listening: The role of auditory function in academics and everyday life [online]. Available at: www.icando.net. Accessed May 26, 2016.

17. Wesson K Learning \& Memory: How Do We Remember and Why Do We Often Forget? [online]. Available at: http://brain world magazine.com. Accessed May 26, 2016.

18. World Health Organization. Health Impact Assessment (HIA) [Online] 2016.

19. Kochanska G Toward a Synthesis of Parental Socialization and Child Temperament in Early Development of Conscience. Child Development, 2008; 64, 325-347.

20. Sam A, \& Wright I The structure of moral reasoning in hearing-impaired students. Am Ann Deaf, 1988; 133, 264-9.

21. Schildroth A Hearing-Impaired Children under Age 6 - 1977 and 1984. American Annals of the Deaf, 1986; 131, 85-90.

22. Teele DW, Klein JO, Chase C, Menyuk P, \& Rosner BA. Otitis-Media in Infancy and Intellectual Ability, School-Achievement, Speech, and Language at Age 7 Years. Journal of Infectious Diseases, 1990; 162, 685.

23. White KR Universal newborn hearing screening: Issues and evidence. CDC Workshop on Early Detection and Intervention, 1997 Atlanta, Georgia.

24. Davis JM, Elfenbein J, Schum R, \& Bentler RA. Effects of mild and moderate hearing impairments on language, educational and psychosocial behavior of children. Journal of Speech and Hearing Disorders, 1986; 51, 053062. 
25. Yoshinaga-Itano C, Sedey AL, Coulter DK, \& Mehl AL Language of early and later identified children with hearing impairment. Pediatrics, 1998; 102, 1161-1171.

26. Tambs K Moderate effects of hearing impairment on mental health and subjective well-being: results from the nord-trondelag hearing impairment study. Psychosomatic Medicine, 2004; 66, 776-782.

27. Saari NH, Umat C, \& Teh KSM Factors affecting the learning of the Holy Quran among severely and profoundly hearing-impaired children with a cochlear implant. Journal of Humanities and Social Science (JHSS), 2013; 2(1), 85-92.

28. Harun AF Masalah penguasaan bacaan asas solat dalam kalangan pelajar bermasalah pendengaran di Politeknik Tuanku Syed Sirajuddin. Available at: http: // www.ptss.edu.my/v6/index.php? option=com_docman\&task $=$ doc_details\&gid $=60 \&$ Itemid=185. Accessed September 15, 2016.

29. Awang@Husain MH, Zakaria HB, Shafie BHM, \& Talib NHF Pendidikan Islam golongan masalah pendengaran: Tinjauan awal isu dan cabaran dari perspektif guru. Seminar Pengajian Islam Menjana Keintelektualan Ummah, At Universiti Sains Islam Malaysia, 2010.

30. Ishak H, Tamuri AH, Majid RA, Bari S Pendidikan Islam golongan masalah pendengaran: tinjauan awal isu dan cabaran dari perspektif guru. Journal of Islamic and Arabic Education, 2012; 4 (2), 11-24.

31. Auda J Maqasid Al-Shariah A Beginner's Guide (Vol. 14). IIIT 2008.

32. Hasnain R, Shaikh LC, \& Shanawani H Disability and the Muslim perspective: An introduction for rehabilitation and health care providers. 2008.

33. Cadha S Increasing community awareness of ear and hearing health. Community ear and hearing health, 2013; 10 (13), 1-12.

34. Antonopoulou K, Hadjikakou K, Stampoltzis A, \& Nicolaou N Parenting styles of mothers with deaf or hard-of-hearing children and hearing siblings. Journal of deaf studies and deaf education, 2012; 17(3), 306-318.

35. Macaulay CE, \& Ford RM Family influences on the cognitive development of profoundly deaf children: exploring the effects of socioeconomic status and siblings. Journal of deaf studies and deaf education, 2013; ent019.

36. Yakan F, \& Hamidi AM Apa ertinya saya menganut Islam. Dewan Pustaka Fajar, 1992.

37. As-Suyuti JA Al-Asybah Wan Nadho'ir Fi Qowa'idi Wa Furu'l Fiqhis Syafi'iyah. Arab Saudi: Maktabah Nazzar Al-Baz. 1997.

38. Moeller MP, Tomblin B, Yoshinaga-Itano C, Connor CM, \& Jerger S Current State of Knowledge: Language and Literacy of Children with Hearing Impairment. Ear \& Hearing 2007; 28; 740-753.

39. Aladabas RA Special Education in Saudi Arabia: History and Areas for Reform. Creative Education, 2015; 6, 1158-1167.

40. Islamweb.deaf. Available at: http:// deaf.islamweb.net/deaf/index.php. Accessed
May 26, 2016.

41. Elhadj YOM Multimedia Educational Content for Saudi Deaf .ICONIP 2012, Part IV, LNCS 7666, pp. 164-171, 2012.

42. Alisharah Available at: http://www. alisharah.com/. Accessed May 26, 2016.

43. Global Deaf Muslim Canada. Available at: http://www.globaldeaf muslimcanada. com/. Accessed May 26, 2016.

44. Malaysia Ministry of Education, Kurikulum Standard Prasekolah Kebangsaan Pendidikan Khas(Masalah Pendengaran). Bahagian Pembangunan Kurikulum, n.d.

45. Malaysia Ministry of Education. Panduan Dasar Pelaksanaan Program j-QAF Pendidikan Khas. Bahagian Pendidikan Khas, n.d.

46. Mohd Daud NA, Jomhari N, \& Abdull Zubi NI. FAKIH: A Method to Teach Deaf People "Reading" Quran. Proceedings: The 2nd Annual International Qur'anic Conference 2012, 53-67.

47. Ghadim N, Jomhari N, \& Alias N Mother's Perspective Toward al-Quran Education for Hearing Impaired Children in Malaysia. Malaysian Online Journal of Educational Technology, [serial online] 2013; 1(4), 26-30. Available at: http://www.mojet.net/volume/ mojet-volume01-issue04.pdf\#page $=32$

48. Sayuti M, Sabdan B, Alias N, \& Jomhari N The Usability Evaluation Of Fakih Method Based On Technology For Students With Hearing Difficulties: The User's Retrospective. The Malaysian Online Journal of Educational Technology, 2012; 2(2), 46-52.

49. Abdul Mutalib A, Yahya S, Nadia S, Salam A, \& Nur $S$ Learning object for the hearing-impaired: Design and development of Koswer Pendidikan Islam Tunakerna (KOSPIT). In: Knowledge Management International Conference (KMICe) 2012, 4 - 6 July 2012, Johor Bahru, Malaysia.

50. Mokhtar SA, \& Anuar SMS Islamic-themed web application for Malaysian Sign Language. In Information and Communication Technology for the Muslim World (ICT4M), 2014. The 5th International Conference on (pp. 1-5). IEEE.

51. Baharudin NS, \& Abdul Majid R, Pembangunan Bahan Pengajaran Dan Pembelajaran Berasaskan Laman Web e-solatpekak.com Untuk Murid Ketidakupayaan Pendengaran Bagi Tajuk Solat Fardu, 2015. Available at: www.Academia.com

52. American Speech-Language-Hearing Association. Year 2007 position statement: principles and guidelines for early hearing detection and intervention programs, 2007.

53. Darrow AA Music therapy in the treatment of the hearing-impaired.Music Therapy Perspectives, 1989; 6(1), 61-70.

54. Bang C A World of Sound and Music. Music Therapy for Deaf, Hearing Impaired and MultiHandicapped Children and Adolescents, 2005.

55. Brandt A, Gebrian M, Slevc LR Music and Early Language Acquisition. Frontier in Psychology. Hypothesis and Theory Article. USA, 2012.

56. Moradi F, \& Shahrokhi M The Effect of Listening to Music on Iranian Children's 
Segmental and Suprasegmental Pronunciation.

English Language Teaching, 2014; 7(6), 128.

57. Pallier $C$ The role of suprasegmentals in speech perception and acquisition.

Phonological structure and language processing: Cross-linguistic studies, 1996; 12, 145.

58. Ismail k, Mohd Azrul Azlen AH Indahnya Hidup Bersyariat; Panduan Fardhu Ain Lengkap Bergambar. Kuala Lumpur: Telaga Biru Sdn. Bhd. 2009.

59. Ibn Qayyim AJ Tuhfat al-Mawdood bi Ahkaam al-Mawlood, 1292.

60. Osman A. Islamic input in medical program: a realization of a holistic medical education. Journal of Education and Social Sciences, 2016; 147-153.

61. Jamilah J, Ahmad Najib A, Dzulkhairi MR, Ariff HO, Nasri Ismail NM Integration of Islamic Input in Medical Curriculum - Universiti Sains Islam Malaysia (USIM) Experience. The International Medical Journal Malaysia. 2014; 73-77.

62. Rabinowitz PM Noise induced hearing impairment. American Family Physician, 2000; 61(9), 2749-2756.

63. Rosen EJ, Vrabec JT, \& Quinn FB Noise induced hearing impairment. Grand Rounds Presentation, UTMB, Dept of Otolaryngology, 2001. Available at: http://www2.utmb.edu/ otoref/Grnds/Hear-Loss-Noise-000110/HearLoss-Noise.doc. Accessed April 10, 2012.

64. Nelson DI, Nelson RY, Concha-Barrientos M, \& Fingerhut $M$ The global burden of occupational noise-induced hearing impairment. American J of Industrial Medicine, 2005; 48, 446-458.

65. Franks JR, Stephenson MR, \& Merry CJ

Preventing occupational hearing impairment: A practical guide. Cincinnati, Ohio: NIOSH, 1996. Available at: http://www.who.int/ occupational_health/publications/noise11.pdf

66. Ismail $N$ The effectiveness occupational noise management in Malaysia. Unpublished manuscript, Department of Linguistics, Macquarie University, Sydney, Australia, 2013.

67. Gerges SNY, Vedsmand L, \& Lester H Personal measures and hearing conservation. In $\mathrm{B}$. Goelzer, C. Hansen \& G. A. Sehrndt (Eds.), Occupational Exposure to Noise: Evaluation, Prevention and Control (pp. 297-316): World Health Organization (WHO), 2001. Available at: http://www.who.int/occupational_health/ publications/noise11.pdf

68. Timmins $P$, \& Granger O Occupational noiseinduced hearing impairment in Australia:

Overcoming barriers to effective noise control and hearing impairment prevention. Safe Work Australia, Barton ACT, 2010.

69. Factories \& Machinery Act 1967. Department of Occupational Safety and Health.

70. Factories \& Machinery (Noise Exposure)

Regulations 1989. Department of Occupational Safety and Health. 
